\title{
The Effect of Tai Chi Chuan on Negative Emotions in Non-Clinical Populations: A Meta-Analysis and Systematic Review
}

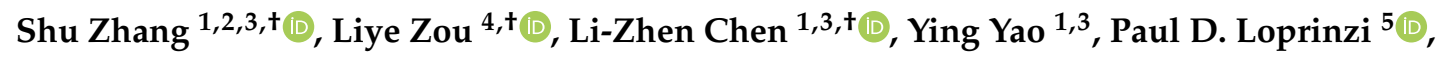 \\ Parco M. Siu ${ }^{6}$ and Gao-Xia Wei ${ }^{1,2, *(D)}$ \\ 1 Key Laboratory of Behavioral Science, Institute of Psychology, Chinese Academy of Sciences, \\ Beijing 100101, China \\ 2 Key Laboratory of Mental Health, Institute of Psychology, Chinese Academy of Sciences, \\ Beijing 100101, China \\ 3 Department of Psychology, University of Chinese Academy of Sciences, Beijing 100049, China \\ 4 Exercise and Mental Health Laboratory, School of Psychology, Shenzhen University, Shenzhen 518061, China \\ 5 Exercise Psychology Laboratory, Department of Health, Exercise Science and Recreation Management, \\ University of Mississippi, 215 Turner Center, Oxford, MS 38677, USA \\ 6 Division of Kinesiology, School of Public Health, Li Ka Shing Faculty of Medicine, \\ The University of Hong Kong, Pokfulam, Hong Kong 999077, China \\ * Correspondence: weigx@psych.ac.cn; Tel.: +86-010-6485-0898 \\ + These authors contributed equally to this work.
}

Received: 29 July 2019; Accepted: 16 August 2019; Published: 21 August 2019

\begin{abstract}
Tai Chi Chuan (TCC) as a typical mind-body practice has been investigated for its preventive role on negative emotions and has demonstrated its efficacy in healthy populations. However, the results are not consistent. We performed a meta-analysis and systematically evaluated the effect of TCC on selected negative emotions (i.e., anxiety and depression). Fourteen experimental studies from three English-and two Chinese-language databases were evaluated. The results showed that the positive effects of TCC on negative emotions were moderately to largely significant. In addition, although TCC significantly improved negative emotions in both the young adults and the older adults, old adults benefited more from TCC than young adults. These findings suggest that TCC is a worthy complementary non-pharmacological resource towards depression and anxiety and, thus, has great implications for the public health domain.
\end{abstract}

Keywords: Tai Chi Chuan; prevention; depression; anxiety; exercise

\section{Introduction}

The World Health Organization reported that about $8 \%$ of the world's population suffers from depression and anxiety, which are one of the leading causes of disability and mortality across the lifespan [1]. Emotional disorders not only exert significant impact on individual health and quality of life, but place enormous burden on family and society as well. However, more than $80 \%$ of people do not seek treatment in developing countries and only 35-50\% in high-income countries receive minimally adequate treatment [2] because of barriers such as high cost, limited valid treatments and diagnosis difficulty. Moreover, the recognized treatments for emotional disorders, namely, pharmacological therapy and psychotherapy, have been criticized for inconsistent clinical outcomes and side effects [3,4]. Given the current limitations in effectiveness of treatment modalities for emotional disorders, the WHO suggested that the most suitable method for reducing the burden caused by 
these disorders is prevention [5]. Hence, prevention (instead of intervention) among the non-clinical population with emotional symptoms is of great importance [6].

There is a wide range of evidence-based preventive strategies available, which have been found to reduce risk factors and strengthen protective factors relating to emotional disorders. Among these preventive approaches, exercise intervention (e.g., running, brisk walking, Yoga, and Tai Chi Chuan) (TCC) could provide both physical and psychological benefits [7]. Recently, accumulating evidence demonstrates a preventive effect of physical exercise on decreasing negative emotions in non-clinical populations. In a study involving 16,483 university undergraduates, self-reported exercise was correlated with lower depression, after controlling for age and sex [8]. Similarly, longitudinal studies among non-clinical populations indicates that physical exercise is an efficient tool to alleviate depression and decrease anxiety $[9,10]$. In addition to physical exercise, those alternative interventions, including mind-body practice such as TCC, Yoga, Qigong as well as mindfulness, have been widely investigated [11].

TCC is one of the Chinese traditional mind-body exercises originated from Taoism philosophy (peaceful/harmonious and holistic principle) with hundreds of years of history [12]. Notably, it seeks for the state of being aware of the permanent, unchanging center of your being as well as mind emptiness by sequence practice and slow movements, which is rooted rom Taoist neigong systems. It emphasizes the coordination of mind and body as well as simultaneous focus on relaxation and concentration. Moreover, TCC movement is relatively gentle and slow, and it does not need a special field or equipment; thus, it has been widely spread in Western countries as an alternative medicine to improve mental and physical health [13-15] among individuals with a metabolic syndrome [16], neurological disorder [17], cardiovascular disease [18] or fibromyalgia [19]. A growing number of clinical studies have also shown that TCC can decrease depression [20] and reduce anxiety [21] in patients with emotional disorders. Regarding the significance of prevention towards emotional disorders, it is important to investigate the potential value of TCC in non-clinical populations. Emergent studies have explored the effect of varied TCC styles on alleviating negative emotions in college students, adults and older adults; however, these studies obtained inconsistent findings. Therefore, the effect that TCC has on negative emotions in non-clinical populations remains largely unknown. Furthermore, due to different study designs, varied outcome measurements and multiple practice protocols, the findings from these studies remain inconclusive. There is no systematic study that has evaluated the effect of TCC on negative emotions in non-clinical populations. In this study, we aimed to conduct a comprehensive review of the effect that TCC has on depression and anxiety.

\section{Materials and Methods}

\subsection{Literature Search}

The Preferred Reporting Item for Systematic Reviews and Meta-Analysis guideline was employed for the procedures of this systematic review [22]. Three English-language (Pubmed, Web of Science and EBSCO) and two Chinese-language databases (China National Knowledge Infrastructure and Wanfang) were searched from inception to February 2019. To obtain a maximum of relevant studies, we used two groups of keywords: (1) "mind-body exercise" OR "mindful exercise" OR "meditative movement" OR "mindfulness-based exercise" OR "Tai Chi" OR "Taiji" OR "mind-body practice" OR "mind-body intervention"; (2) "affective" OR "mood" OR "emotion" OR "depression" OR "anxiety". Additionally, we manually searched relevant studies from reference lists of the initially retrieved articles and reviews.

\subsection{Inclusion Criteria and Study Selection}

Studies were only included in this review if they met the following inclusionary criteria: (1) experimental studies published in peer-review journals; (2) involving participants with no physical and/or mental disorder; (3) TCC as an exercise intervention program; (4) at least one outcome measure 
(depression and/or anxiety) associated with negative emotion; (5) obtainable quantitative data for effect size calculation. Studies that did not meet the above-mentioned inclusion criteria were excluded (e.g., single-group study with pre-test/post-test design). All retrieved records were initially screened by three independent review authors (S.Z., L.Z.C. and Y.Y.). Further evaluation on uncertain records was conducted by a fourth review author (G.X.W.).

\subsection{Methodological Quality Assessment of Included Studies}

We used the Physiotherapy Evidence Database (PEDro) Scale [23] to assess methodological quality of all included studies. It consists of 11 evaluation items as follow: eligibility criteria, random allocation, concealed allocation, baseline equivalence, participants blinding, instructor blinding, assessor blinding, retention rate $\geq 85 \%$, intention-to-treat analysis for missing data, between-group statistical comparison and point measure/measure of variability $\geq$ one key outcome. Given that the blinding of participants and instructors is impossible during TCC intervention, these two items (instructors blinding and subjects blinding) were removed from the scale. The evaluation was completed by three independent reviewers who examined each individual item to objectively evaluate risk of bias (e.g., selection, performance, detection or attention) across trails, but did not summarize methodological quality of each trial according to its sum score. The detailed information on quality assessment is summarized in Tables 1 and 2.

Table 1. The experimental characteristics of all selected trials.

\begin{tabular}{|c|c|c|c|c|c|}
\hline Studies & Study Area & $\begin{array}{c}\text { Study } \\
\text { Design }\end{array}$ & Sample Size (N) & Female (\%) & Mean Age (Years) \\
\hline Bao et al. 2015 & $\begin{array}{l}\text { China, } \\
\text { Mainland }\end{array}$ & PPCGD $^{1}$ & TCC $^{2}: 73 ; \mathrm{C}^{3}: 69$ & TCC: $52.1 ; C: 52.2$ & TCC: $14.8 ; \mathrm{C}: 14.7$ \\
\hline Chang et al. 2013 & $\begin{array}{l}\text { China, } \\
\text { Taipei }\end{array}$ & $\mathrm{QED}^{4}$ & TCC: $64 ; C: 69$ & TCC: $53.1 ; C: 65.2$ & TCC: $56.5 ; C: 62.3$ \\
\hline Frith et al. 2011 & Australia & Field study & $\begin{array}{l}\text { TCC: } 29 ; \mathrm{C} 1\left(\mathrm{CI}^{5}\right): \\
\text { 30; } 22\left(\mathrm{AE}^{6}\right): 34\end{array}$ & $\begin{array}{c}\text { TCC: } 62.1 ; C 1: \\
53.3 ; C 2: 50\end{array}$ & $\begin{array}{c}\text { TCC: } 37.2 ; \mathrm{C} 1: 30 ; \\
\text { C2: } 27.7\end{array}$ \\
\hline Frye et al. 2007 & USA & $\mathrm{RCT}^{7}$ & $\begin{array}{c}\text { TCC: } 23 ; \operatorname{LIE}^{8}: 28 \\
\text { C: } 21\end{array}$ & Total: 54 & Total: 69.2 \\
\hline Gallegos et al. 2016 & Spain & $\mathrm{RCT}$ & $\begin{array}{c}\text { TCC: } 68 ; \mathrm{Y}^{9}: 85 ; \mathrm{M} \\
\text { 10: } 84 ; \mathrm{C}: 45\end{array}$ & Total: 54.6 & Total: 20.3 \\
\hline Hong et al. 2017 & $\begin{array}{l}\text { China, } \\
\text { Mainland }\end{array}$ & PPCGD & TCC: $60 ; C: 60$ & TCC: $50 ; C: 50$ & NR \\
\hline Li, A et al. 2006 & $\begin{array}{l}\text { China, } \\
\text { Mainland }\end{array}$ & PPCGD & TCC: $59 ; C: 59$ & Total: 47.5 & NR \\
\hline Li, F et al. 2001 & USA & $\mathrm{RCT}$ & TCC: $40 ; C: 32$ & Total: 75 & Total: 73.2 \\
\hline Liao et al. 2018 & $\begin{array}{c}\text { China, } \\
\text { Mainland }\end{array}$ & $\mathrm{RCT}$ & TCC: 55; C: 52 & TCC: $65.5 ;$ C:57.7 & TCC: $71.84 ; C: 71.8$ \\
\hline Noradechanunt et al. 2017 & Australia & $\mathrm{RCT}$ & TCC: 9; Y: 11; C: 10 & $\begin{array}{c}\text { TCC: } 69.2 ; \text { Y: } 76.9 \\
\text { C: } 76.9\end{array}$ & $\begin{array}{c}\text { TCC: } 67.2 ; \text { Y: } 67.6 \\
\text { C: } 65.2\end{array}$ \\
\hline Sattin et al. 2005 & USA & $\mathrm{RCT}$ & TCC: 92; WE ${ }^{11}: 82$ & TCC: 95; WE: 94 & TCC: 80.4; WE: 80.5 \\
\hline Schitter et al. 2016 & Switzerland & PPCGD & TCC: $28 ; C: 31$ & Total: 66.7 & Total: 35.5 \\
\hline Zhang et al. 2014 & $\begin{array}{c}\text { China, } \\
\text { Mainland }\end{array}$ & $\begin{array}{l}\text { Five-arm } \\
\text { RCT }\end{array}$ & $\begin{array}{l}\text { TCC: } 28 ; \text { Swim }^{12} \text { : } \\
\text { 29; Run } 13: 27 ; \text { SD } \\
\quad \text { 14: } 30 ; C: 30\end{array}$ & TCC: $53.6 ; C: 46.7$ & TCC: $65.5 ;$ C: 64.1 \\
\hline Zheng et al. 2017 & Australia & $\begin{array}{l}\text { Three-arm } \\
\text { RCT }\end{array}$ & $\begin{array}{c}\text { TCC: } 17 ; \operatorname{Ex}^{15}: 17 \\
\text { C: } 16\end{array}$ & $\begin{array}{l}\text { TCC: } 64.7 ; \text { Ex: } \\
82.4 ; \text { C: } 87.5\end{array}$ & $\begin{array}{c}\text { TCC: } 35.4 ; \text { Ex: 32; } \\
\text { C: } 34.6\end{array}$ \\
\hline \multicolumn{6}{|c|}{$\begin{array}{l}{ }^{1} \text { PPCGD: Pre and post-test control group design; }{ }^{2} \text { TCC: Taichi Chuan; }{ }^{3} \text { C: Control; }{ }^{4} \text { QED: Quasi experimental } \\
\text { design; }{ }^{5} \text { CI: circuit training; }{ }^{6} \text { AE: aerobic exercise; }{ }^{7} \text { RCT: random control trial; }{ }^{8} \text { LIE: low impact exercise; }{ }^{9} \text { Y: Yoga; } \\
\text { M: Mindfulness; }{ }^{11} \text { WE: Wellness Education; }{ }^{12} \text { Swim: swimming; }{ }^{13} \text { Run: running; }{ }^{14} \text { SD: Square Dancing; }{ }^{15} \text { Ex: } \\
\text { Exercise; NR: not reported. }\end{array}$} \\
\hline
\end{tabular}


Table 2. The intervention characteristics of all selected trials.

\begin{tabular}{|c|c|c|c|c|c|}
\hline Studies & TCC Style & $\begin{array}{l}\text { Weekly } \\
\text { Dosage }\end{array}$ & Duration & $\begin{array}{l}\text { Supervisor } \\
\text { (Y or N) }\end{array}$ & Emotion Outcomes \\
\hline Bao et al. 2015 & Yang style & $60 \min \times 5$ & 1 year & $\mathrm{Y}^{1}$ & PHCSCS $^{3}$ \\
\hline Chang et al. 2013 & Cheng Style & $60 \min \times 3$ & 12 weeks & $\mathrm{Y}$ & $\mathrm{BAI}^{4}$ \\
\hline Frith et al. 2011 & $\mathrm{~N} / \mathrm{A}^{5}$ & $5 \sim 10 \min \times 3$ & $5-10 \mathrm{~min}$ & $\mathrm{Y}$ & TESI ${ }^{6}$ VAS $^{7}$ \\
\hline Frye et al. 2007 & Yang style & $60 \min \times 3$ & 12 weeks & Y & STAI $^{8}$ SAS $_{10}^{9}$ CES-D \\
\hline Gallegos et al. 2016 & \begin{tabular}{l}
\multicolumn{1}{c}{ Tsung } \\
Hwa/Canneti/Rooting/ \\
Chen style (Mixed)
\end{tabular} & $30 \min \times 2$ & $30 \times 2 \min$ & Y & DASS-21 ${ }^{11}$ \\
\hline Hong et al. 2017 & N/A & $60 \min \times 4$ & 2 months & NR & SCL-90 ${ }^{12}$ \\
\hline Li, A et al. 2006 & N/A & $30 \min \times 5$ & 15 weeks & NR & SCL-90 \\
\hline Li, F et al. 2001 & $\begin{array}{l}\text { Condensed, } \\
\text { classical Yang form }\end{array}$ & $60 \min \times 2$ & 24 weeks & Y & $\begin{array}{c}\text { CESD-20 } 13 \\
\text { PANAS-20 }{ }^{14} \text { PWPD } \\
{ }^{15} \text { SWLS }^{16}\end{array}$ \\
\hline Liao et al. 2018 & Yang Style & $50 \min \times 3$ & 3 months & $\mathrm{N} / \mathrm{A}$ & GDS ${ }^{17}$ \\
\hline Noradechanunt et al. 2017 & $\begin{array}{l}12 \text { Movement Sun } \\
\text { style }\end{array}$ & $60 \min \times 2$ & 12 weeks & $\mathrm{N}^{2}$ & CES-D \\
\hline Sattin et al. 2005 & N/A & $60 \sim 90 \min \times 2$ & 48 weeks & $\mathrm{Y}$ & CES-D \\
\hline Schitter et al. 2016 & Yang style & $60 \min \times 2$ & 12 weeks & $\mathrm{Y}$ & CES-D ADS-K ${ }^{18}$ \\
\hline Zhang et al. 2014 & N/A & $30 \sim 60 \min \times 3$ & 18 months & Y & $\begin{array}{c}\text { SECF }^{19} \text { HAMA }^{20} \\
\text { HAMD }^{21}\end{array}$ \\
\hline Zheng et al. 2017 & Sim-24 & $60 \min \times 2$ & 12 weeks & $\begin{array}{l}\text { Y (First } \\
6 \text { weeks) }\end{array}$ & STAI PSS ${ }^{22}$ SF-36 ${ }^{23}$ \\
\hline \multicolumn{6}{|c|}{$\begin{array}{l}{ }^{1} \text { Y: Yes; }{ }^{2} \text { N: No; }{ }^{3} \text { PHCSCS: Piers-Harris Children's Self-Concept Scale; }{ }^{4} \text { BAI: The Beck Anxiety Inventory; } \\
{ }^{5} \text { N/A: Not reported; }{ }^{6} \text { TESI: Tension and Effort Stress Inventory; }{ }^{7} \text { VAS: A bipolar visual analogue scale; }{ }^{8} \text { STAI: } \\
\text { the State-Trait Anxiety Inventory; }{ }^{9} \text { SAS: Spielberger Anxiety Scale; }{ }^{10} \text { CES-D: the Center for Epidemiological } \\
\text { Studies Depression Scale; }{ }^{11} \text { DASS-21: the Depression Anxiety Stress Scales; }{ }^{14} \text { SCL-90: Self-reporting Inventory-90; } \\
{ }^{13} \text { CESD-20: } 20 \text {-item Center for Epidemiologic Studies Depression scale; }{ }^{14} \text { PANAS-20: the } 20 \text {-item Positive and } \\
\text { Negative Affect Schedule; }{ }^{15} \text { PWPD: Positive well-being and psychological distress (subscale of the Subjective } \\
\text { Exercise Experiences); }{ }^{16} \text { SWLS: the Satisfaction with life scale; }{ }^{17} \text { GDS: the Geriatric Depression Scale; }{ }^{18} \text { ADS-K: } \\
\text { Allgemeine Depressionsskala -Kurzform questionnaire; }{ }^{19} \text { SECF: SECF Cognitive Scale; }{ }^{20} \text { HAMA: Hamilton Anxiety } \\
\text { Scale; }{ }^{21} \text { HAMD: Hamilton Depression Scale; }{ }^{22} \text { PSS: The Perceived Stress Scale; }{ }^{23} \text { SF-36: } 36 \text {-item short form survey. }\end{array}$} \\
\hline
\end{tabular}

\subsection{Data Extraction and Analysis}

Two review authors independently extracted descriptive information related to study characteristics: (1) participants (age, ratio of female and sample size); (2) TCC intervention protocol (weekly dosage, total time and qualified instructor); (3) outcomes (e.g., depression and/or anxiety) and instruments. To investigate the beneficial effects of TCC on negative emotions, we also extracted quantitative data (depression and/or anxiety).

If a study included one TCC group and two control groups (active and non-active control conditions), we only selected the non-active control-like wait-list to compare with the TCC intervention. In addition, if there were two or more active control groups (aerobic exercise, Yoga, mindfulness), we only selected the non-mindfulness-based intervention since TCC has shared similar components with Yoga and mindfulness. If two instruments measured depression, we selected the most frequently used instrument across the included studies.

To calculate pooled effect size (Standardized mean difference: SMD, negligible effect: $0-0.19$; small effect: 0.2-0.49; moderate effect: 0.5-0.79; and large effect: $>0.8$ [9]), we used the Comprehensive Meta-Analysis Software (Bio. Stat. Inc., Englewood, NJ, USA) based on the number of participants of each group and its quantitative data (mean and standard deviation) at baseline and post-intervention. The random-effect model was selected along with 95\% confidence interval (95\% CI). I-squared was used to determine heterogeneity ( small $=25 \%$, moderate $=50 \%$ and large $=75 \%$ ) across the selected 
studies. Finally, the funnel plot and Egger's regression intercept test were employed to determine whether publication bias existed. Furthermore, we performed subgroup analysis for age range: (1) adults aged between 18 and 65 and (2) older adults aged 65 and above. Additionally, considering the differences of study design, we conducted a subgroup analysis based on study design.

\section{Results}

\subsection{Study Selection}

Both electronic and manual searches resulted in 3689 records in total. After removing the duplication and irrelevant articles, 353 full-text articles were assessed according to the pre-determined inclusion criteria, leading to a final number of 14 eligible experimental studies, including two Chinese articles. The process of study selection is shown in detail in Figure 1.
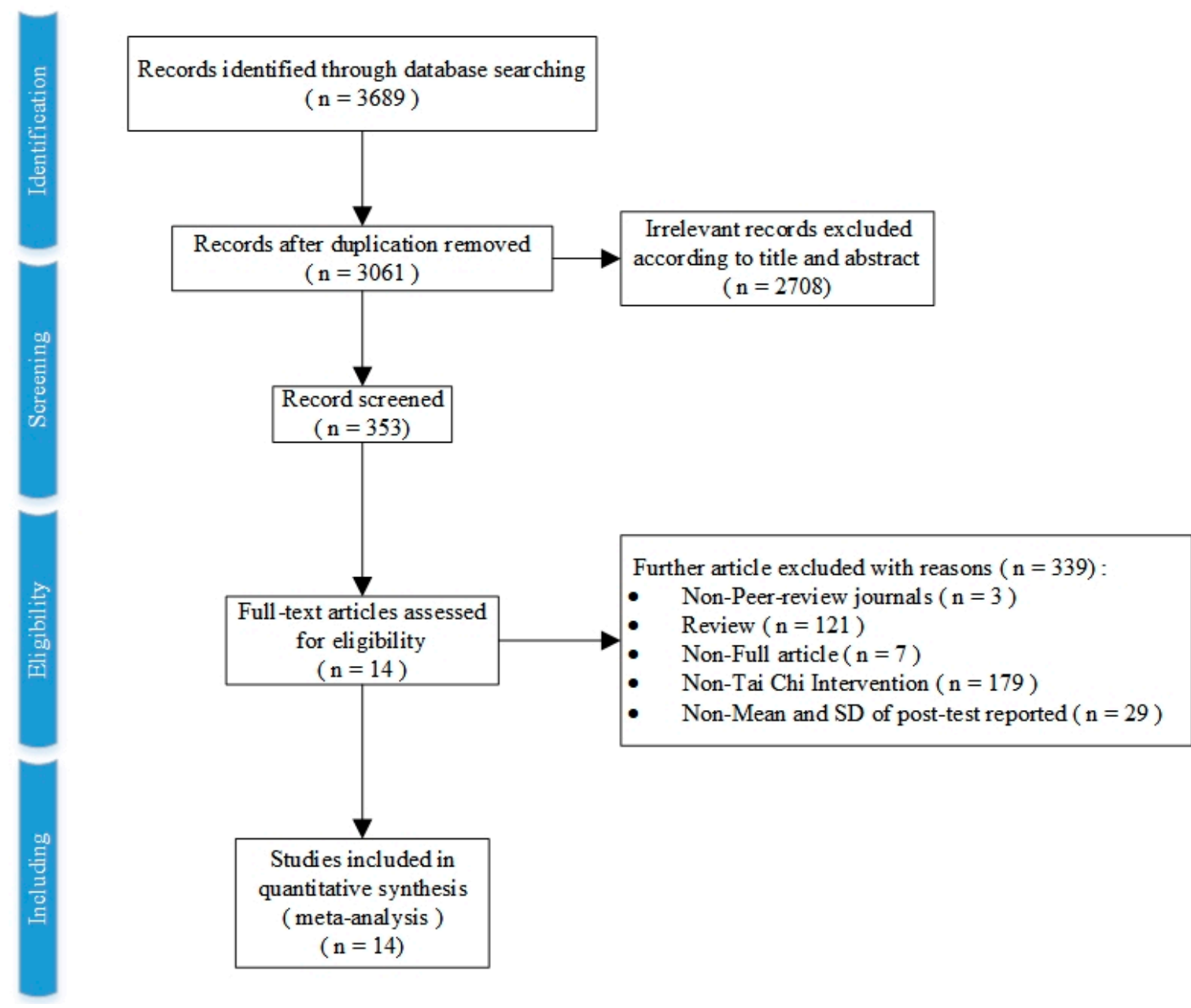

Figure 1. The detailed process of trial selection.

\subsection{Study Characteristics}

As is depicted in the Tables 1 and 2, the evaluated studies were published from inception to December 2018. Six studies were conducted in China, three in the USA, two in Australia, two in Switzerland and one in Spain. The total sample size was $1285($ TCC $=645$; Control $=640)$, with the percentage of female participants ranging from 46.67 to $95 \%$. The mean age of each study varied from 14.79 to 80.5 years old. Both long-term intervention studies $(n=12)$ and short-term intervention studies $(n=2)$ were included in this review. For long-term intervention studies, the intervention duration 
lasted from 12 weeks to 18 months. Furthermore, 71.43\% (10 studies) involved TCC supervisors during the intervention.

\subsection{Study Quality Assessment}

Table 3 displays the study quality of all evaluated studies. To calculate the PEDro score, if the item was not mentioned in the paper, we signed a 0 for this item in the PEDro table. In detail, one study scored 4, three studies scored 5, six studies scored 6, two studies scored 7 and two studies scored 8. The selected studies indicated fair-to-high (sum scores ranged from 4 to 8 ) study quality, with the mean quality score was 6.07. Furthermore, all selected studies met item 7-9 of the PEDro scale and four of selected studies did not clarify their specified criteria for participants.

Table 3. Study quality assessment of all selected trials.

\begin{tabular}{|c|c|c|c|c|c|c|c|c|c|c|}
\hline Studies & Item $1^{1}$ & Item $2^{2}$ & Item $3^{3}$ & Item $4^{4}$ & Item $5^{5}$ & Item $6^{6}$ & Item $7^{7}$ & Item $8^{8}$ & Item $9^{9}$ & Score \\
\hline Bao et al. 2015 & 0 & 1 & 0 & 1 & 0 & 1 & 1 & 1 & 1 & 6 \\
\hline Chang et al. 2013 & 1 & 0 & 0 & 1 & 0 & 1 & 1 & 1 & 1 & 6 \\
\hline Frith et al. 2011 & 0 & 0 & 0 & 0 & 0 & 1 & 1 & 1 & 1 & 4 \\
\hline Frye et al. 2007 & 1 & 1 & 0 & 1 & 0 & 1 & 1 & 1 & 1 & 7 \\
\hline Gallego et al. 2016 & 0 & 1 & 0 & 1 & 0 & 1 & 1 & 1 & 1 & 6 \\
\hline Hong et al. 2017 & 0 & 1 & 0 & 0 & 0 & 1 & 1 & 1 & 1 & 5 \\
\hline Li, A et al. 2006 & 0 & 1 & 0 & 0 & 0 & 1 & 1 & 1 & 1 & 5 \\
\hline Li, F et al. 2001 & 1 & 1 & 0 & 1 & 0 & 0 & 1 & 1 & 1 & 6 \\
\hline Liao et al. 2018 & 1 & 1 & 0 & 1 & 0 & 1 & 1 & 1 & 1 & 7 \\
\hline $\begin{array}{l}\text { Noradechanunt } \\
\text { et al. } 2017\end{array}$ & 1 & 1 & 0 & 1 & 0 & 0 & 1 & 1 & 1 & 6 \\
\hline Sattin et al. 2005 & 1 & 1 & 0 & 1 & 1 & 1 & 1 & 1 & 1 & 8 \\
\hline Schitter et al. 2016 & 1 & 1 & 1 & 0 & 1 & 1 & 1 & 1 & 1 & 8 \\
\hline Zhang et al. 2014 & 1 & 0 & 0 & 1 & 0 & 0 & 1 & 1 & 1 & 5 \\
\hline Zheng et al. 2017 & 1 & 1 & 0 & 1 & 0 & 0 & 1 & 1 & 1 & 6 \\
\hline
\end{tabular}

Item 1 = specified eligibility criteria; Item 2 = random allocation; Item 3 = concealed allocation; Item 4 = baseline equivalence; Item $5=$ assessor blinding; Item $6=$ retention rate $\geq 85 \%$; Item $7=$ intention-to-treat analysis for missing data; Item 8 = between-group statistical comparison; and Item $9=$ point measure/measure of variability $\geq$ one key outcome.

\subsection{Effects of TCC Intervention on Negative Emotion}

Firstly, all selected studies were entered into the model to analyze the effects of TCC on both negative emotions (depression and anxiety). Conservatively, if a study contained more than one negative emotion, the minimum change score of the negative emotion was selected to be analyzed. The asymmetrical funnel plot was presented (Egger's regression intercept $=-5.216, p=0.144$ ). According to the funnel plot and Egger's regression intercept, two outliers were excluded (Sattin et al., 2005 [15] and Zheng et al., 2017 [24]; Egger's regression intercept $=0.278, p=0.859$ ). The final funnel plot is depicted in Figure 2. This meta-analysis with random model indicated a significant benefit of TCC on negative emotions, as compared to control groups (SMD $=-0.500,95 \%$ CI: -0.677 to -0.541 , $\mathrm{I}^{2}=44.835 \%, p=0.000$, Figure 3 ). 


\section{Funnel Plot of Standard Error by Std diff in means}

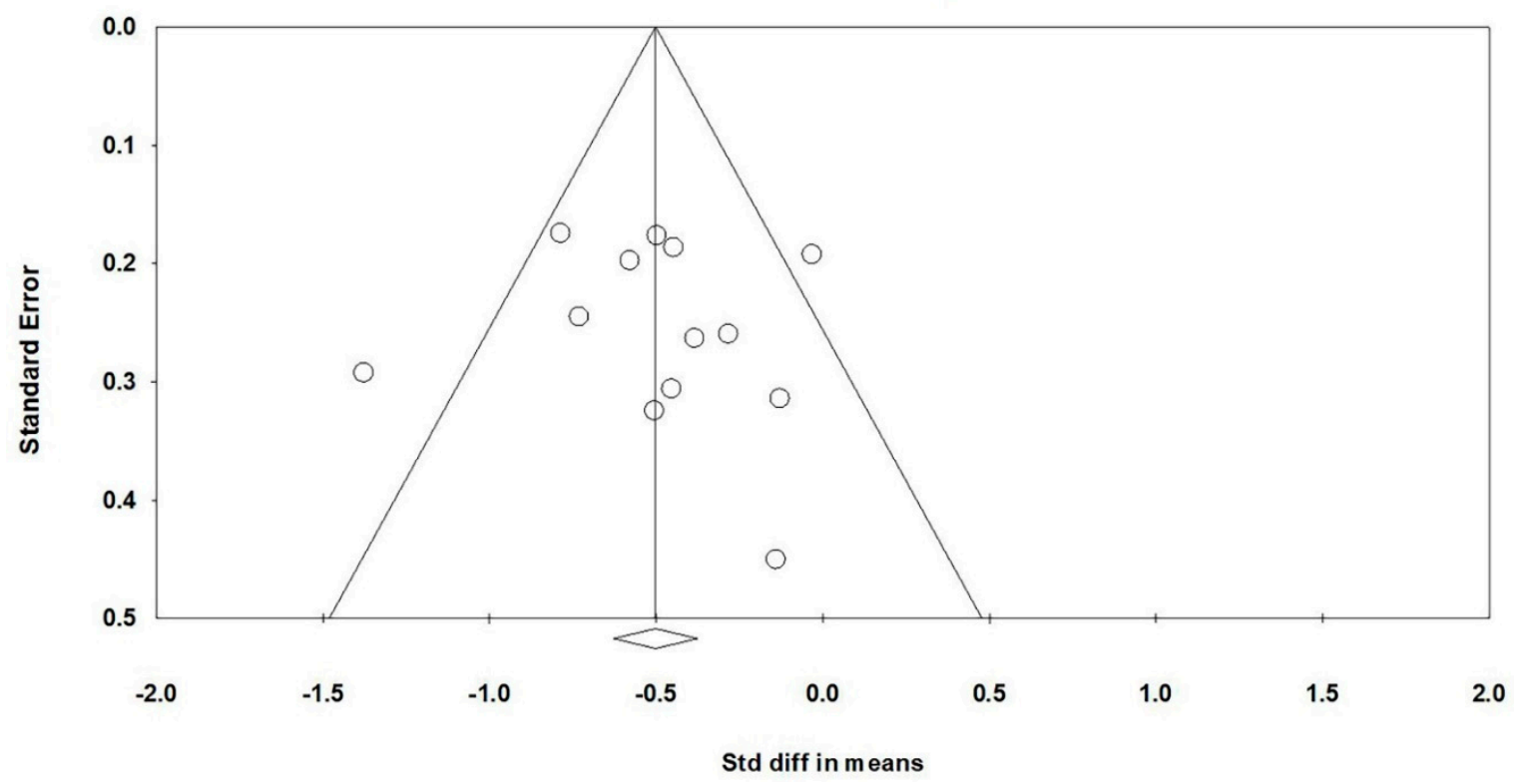

Figure 2. Funnel plot for negative emotions after removing outliers.

\begin{tabular}{|c|c|c|c|c|c|c|c|c|c|c|c|}
\hline \multirow[t]{2}{*}{ Study name } & \multicolumn{7}{|c|}{ Statistics for each study } & \multicolumn{4}{|c|}{ Std diff in means and $95 \% \mathrm{Cl}$} \\
\hline & $\begin{array}{l}\text { Std diff } \\
\text { in means }\end{array}$ & $\begin{array}{c}\text { Standard } \\
\text { error }\end{array}$ & Variance & $\begin{array}{c}\text { Lower } \\
\text { limit }\end{array}$ & $\begin{array}{c}\text { Upper } \\
\text { limit }\end{array}$ & Z-Value & p-Value & & & & \\
\hline Bao et al (2015) & -0.787 & 0.174 & 0.030 & -1.129 & -0.446 & -4.517 & 0.000 & & & & \\
\hline Chang et al (2013) & -0.498 & 0.176 & 0.031 & -0.843 & -0.153 & -2.826 & 0.005 & & & & \\
\hline Frith et al (2011) AE & -0.505 & 0.324 & 0.105 & -1.141 & 0.130 & -1.558 & 0.119 & & & & \\
\hline Frith et al $(2011) \mathrm{Cl}$ & -0.128 & 0.314 & 0.099 & -0.744 & 0.487 & -0.409 & 0.683 & & & & \\
\hline Frye et al (2007) & -0.454 & 0.306 & 0.093 & -1.053 & 0.145 & -1.485 & 0.138 & & & & \\
\hline Gallegos et al (2016) & -0.032 & 0.192 & 0.037 & -0.409 & 0.344 & -0.168 & 0.867 & & & & \\
\hline Hong et al (2017) & -0.283 & 0.259 & 0.067 & -0.792 & 0.226 & -1.090 & 0.276 & & & & \\
\hline $\mathrm{Li}, \mathrm{A}$ et al (2006) & -0.448 & 0.186 & 0.035 & -0.813 & -0.082 & -2.402 & 0.016 & & & & \\
\hline $\mathrm{Li}, \mathrm{F}$ et al (2001) & -0.731 & 0.245 & 0.060 & -1.211 & -0.251 & -2.986 & 0.003 & & & & \\
\hline Liao et al (2018) & -0.579 & 0.197 & 0.039 & -0.966 & -0.192 & -2.931 & 0.003 & & & & \\
\hline Noradechanunt et al (2017) & -0.140 & 0.450 & 0.203 & -1.022 & 0.742 & -0.311 & 0.756 & & & & \\
\hline Schitter et al (2016) & -0.385 & 0.263 & 0.069 & -0.900 & 0.131 & -1.462 & 0.144 & & & & \\
\hline \multirow{4}{*}{ Zhang et al (2014) } & -1.378 & 0.292 & 0.085 & -1.951 & -0.805 & -4.715 & 0.000 & & & & \\
\hline & -0.500 & 0.090 & 0.008 & -0.677 & -0.323 & -5.541 & 0.000 & & & & \\
\hline & & & & & & & & \multirow[t]{2}{*}{-2.00} & -1.00 & 1.00 & 2.00 \\
\hline & & & & & & & & & TCC & Control & \\
\hline
\end{tabular}

Meta Analysis

Figure 3. Forest plot for negative emotions (CI: circuit training; AE: aerobic exercise).

\subsection{Effect of TCC Intervention on Anxiety}

Nine studies (10 paired comparisons) investigated the effects of TCC on anxiety, measured by different instruments (The 80-item PHCSCS, State-trait Anxiety Inventory-state, Hamilton Depression Scale, Depression Anxiety Stress Scales, Unpleasant TESI emotion, Spielberg Anxiety Scale, SCL-90 and Self-rating Anxiety Scale). Two outliers was excluded (Zhang et al., 2014 [25] and Zheng et al., 2017 [24]) in accordance with the asymmetrical funnel plot (before removing outliers: Egger's regression intercept $=-5.956, p=0.036$; after removing outliers: Egger's regression intercept $=2.391, p=0.056$ ). The final funnel plot is depicted in Figure 4. This meta-analysis with random model indicated TCC significantly decreased anxiety, as compared to control groups (SMD $=-0.561,95 \% \mathrm{CI}:-0.714$ to $-0.408, \mathrm{I}^{2}=0.000 \%$, $p=0.000$, Figure 5). 
Funnel Plot of Standard Error by Std diff in means

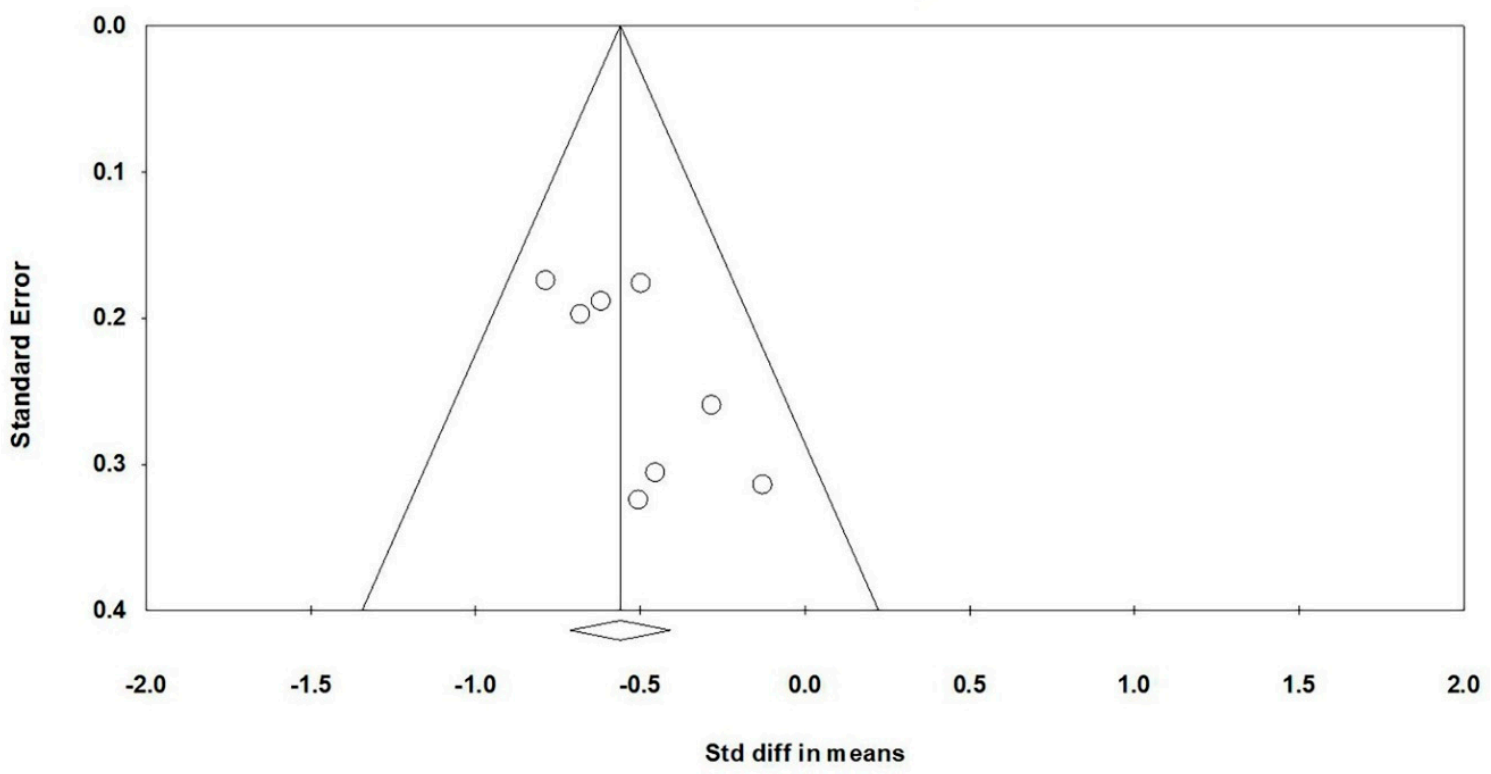

Figure 4. Funnel plot for anxiety after removing outliers.

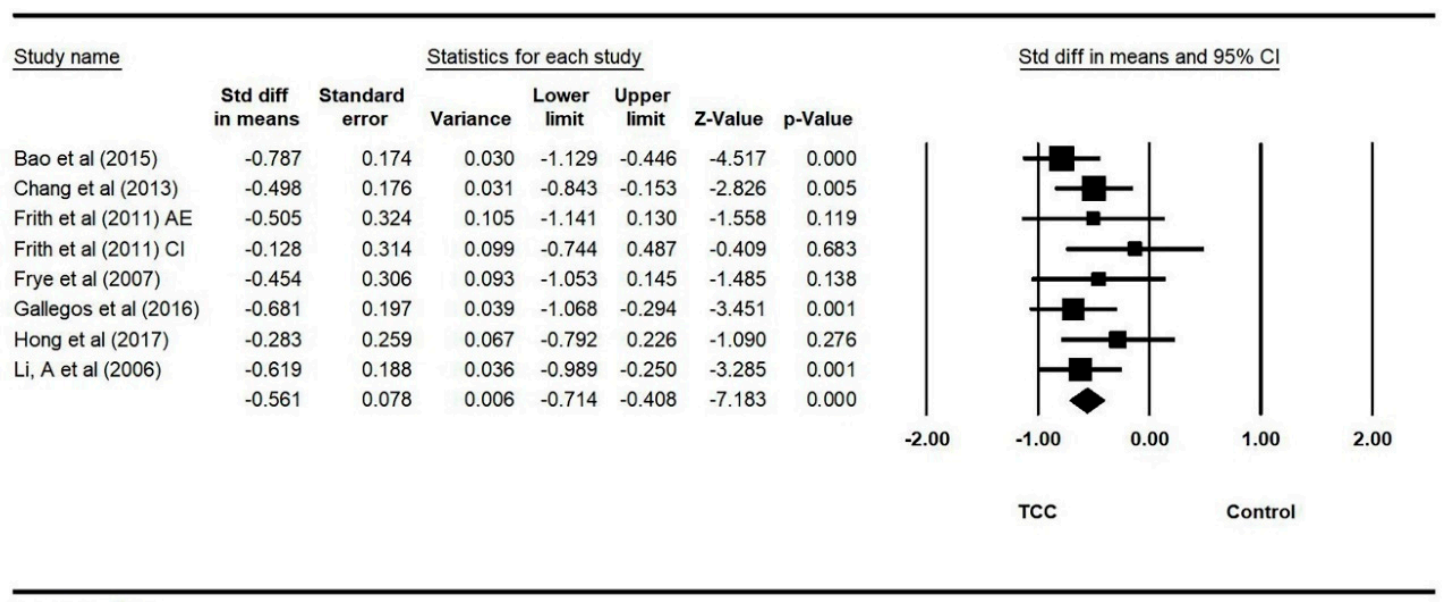

Meta Analysis

Figure 5. Forest plot for anxiety (CI: circuit training; AE: aerobic exercise).

\subsection{Effect of TCC Intervention on Depression}

Additionally, we meta-analyzed the data from nine studies on depression. This outcome was measured by different instruments, with greater scores indicating worse depression. An asymmetric funnel plot was visually observed and presented two outlying studies (Sattin et al., 2005 [15]; Egger's regression intercept $=-6.349, p=0.418$ ). After removing outliers, the funnel plot is symmetrically presented in Figure 6 (Egger's regression intercept $=-1.451, p=0.584$ ). The random model analysis indicated a significant positive effect of TCC on depression (SMD $=-0.495,95 \%$ CI: -0.762 to -0.229 , $\mathrm{I}^{2}=59.790 \%, p=0.000$, Figure 7). 


\section{Funnel Plot of Standard Error by Std diff in means}

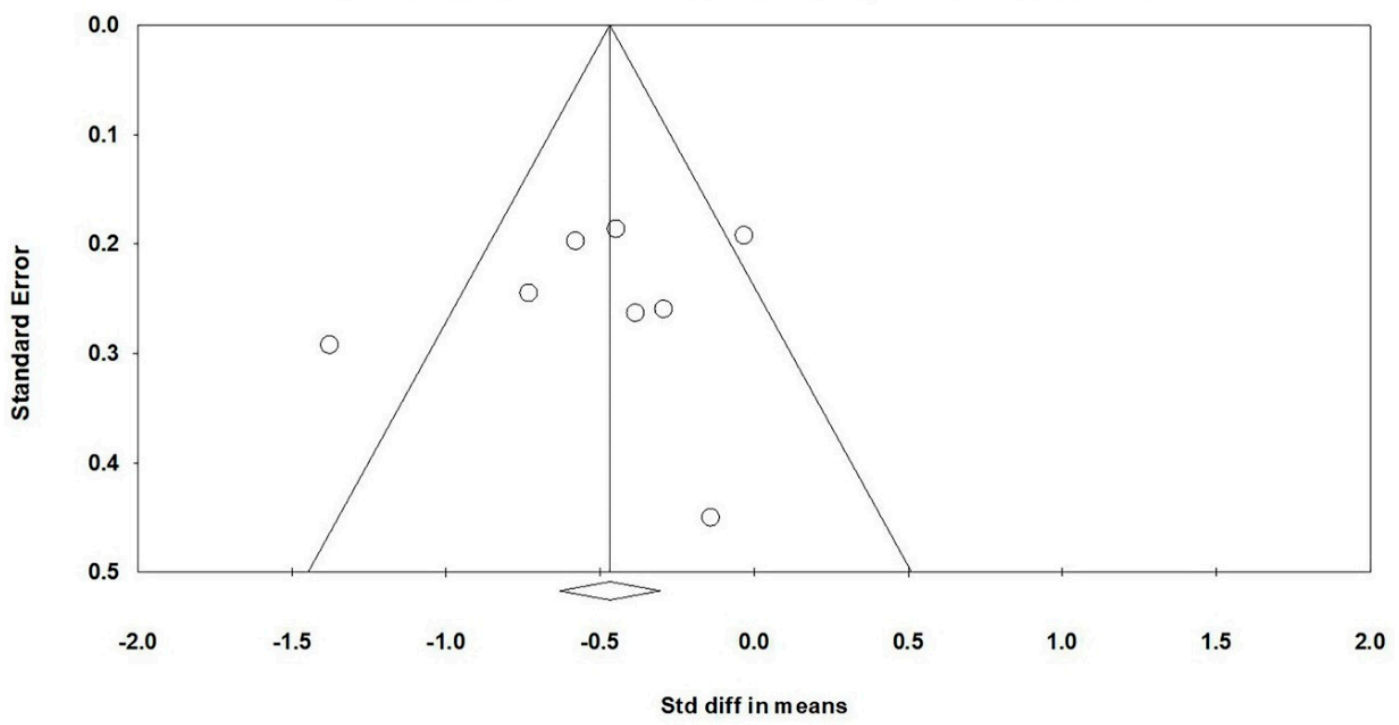

Figure 6. Funnel plot for depression after removing outliers.

\begin{tabular}{|c|c|c|c|c|c|c|c|c|c|c|c|}
\hline \multirow[t]{2}{*}{ Study name } & \multicolumn{7}{|c|}{ Statistics for each study } & \multicolumn{4}{|c|}{ Std diff in means and $95 \% \mathrm{Cl}$} \\
\hline & $\begin{array}{l}\text { Std diff } \\
\text { in means }\end{array}$ & $\begin{array}{l}\text { Standard } \\
\text { error }\end{array}$ & Variance & $\begin{array}{c}\text { Lower } \\
\text { limit }\end{array}$ & $\begin{array}{c}\text { Upper } \\
\text { limit }\end{array}$ & Z-Value & $\mathrm{p}$-Value & & & & \\
\hline Gallegos et al (2016) & -0.032 & 0.192 & 0.037 & -0.409 & 0.344 & -0.168 & 0.867 & & & 1 & \\
\hline Hong et al (2017) & -0.293 & 0.260 & 0.067 & -0.802 & 0.216 & -1.128 & 0.259 & & & & \\
\hline $\mathrm{Li}, \mathrm{A}$ et al (2006) & -0.448 & 0.186 & 0.035 & -0.813 & -0.082 & -2.402 & 0.016 & & & & \\
\hline Li, F et al (2001) & -0.731 & 0.245 & 0.060 & -1.211 & -0.251 & -2.986 & 0.003 & & & & \\
\hline Liao et al (2018) & -0.579 & 0.197 & 0.039 & -0.966 & -0.192 & -2.931 & 0.003 & & & & \\
\hline Noradechanunt et al (2017) & -0.140 & 0.450 & 0.203 & -1.022 & 0.742 & -0.311 & 0.756 & & & & \\
\hline Schitter et al (2016) & -0.385 & 0.263 & 0.069 & -0.900 & 0.131 & -1.462 & 0.144 & & & & \\
\hline \multirow[t]{4}{*}{ Zhang et al (2014) } & -1.378 & 0.292 & 0.085 & -1.951 & -0.805 & -4.715 & 0.000 & & & & \\
\hline & -0.495 & 0.136 & 0.019 & -0.762 & -0.229 & -3.639 & 0.000 & & & ] & | \\
\hline & & & & & & & & \multirow[t]{2}{*}{-2.00} & -1.00 & 1.00 & 2.00 \\
\hline & & & & & & & & & TCC & Control & \\
\hline
\end{tabular}

Meta Analysis

Figure 7. Forest plot for depression.

\subsection{Moderator Analysis for Age}

Although most TCC studies were focused on older populations in view of its features of slow movements with moderate intensity, TCC has been employed in all-aged populations. Among the 14 studies, we found that TCC was also practiced among teenager and younger adults. Therefore, we meta-analyzed moderation analyses for age after removing the only one teenager focused study. Effect sizes were obtained from the selected 10 studies after removing outliers, which investigated the effect in adults $(N=7)$ and older adults $(N=5)$. A significant age moderator effect was found using the random-effect model: $\mathrm{Q}=4.970, \mathrm{df}=1, p=0.026$ (adults: $\mathrm{SMD}=-0.330,95 \% \mathrm{CI}:-0.524$ to -0.137 , $\mathrm{I}^{2}=0.000 \%, p=0.001$; older adults: $\mathrm{SMD}=-0.701,95 \% \mathrm{CI}:-0.946$ to $-0.439, \mathrm{I}^{2}=49.838 \%, p=0.000$, Figure 8). 


\begin{tabular}{|c|c|c|c|c|c|c|c|c|c|c|c|c|c|}
\hline \multirow{2}{*}{$\frac{\text { Group by }}{\text { Age group }}$} & \multirow[t]{2}{*}{$\underline{\text { Study name }}$} & \multicolumn{7}{|c|}{ Statistics for each study } & \multicolumn{5}{|c|}{$\underline{\text { Std diff in means and } 95 \% \mathrm{Cl}}$} \\
\hline & & $\begin{array}{l}\text { Std diff } \\
\text { in means }\end{array}$ & $\begin{array}{l}\text { Standard } \\
\text { error }\end{array}$ & Variance & $\begin{array}{l}\text { Lower } \\
\text { limit }\end{array}$ & $\begin{array}{l}\text { Upper } \\
\text { limit }\end{array}$ & z-value & p-Value & & & & & \\
\hline Adults & Chang et al (2013) & -0.498 & 0.176 & 0.031 & -0.843 & -0.153 & $\begin{array}{ll}3 & -2.826 \\
\end{array}$ & 0.005 & 1 & & & 1 & 1 \\
\hline Adults & Frith et al (2011) AE & -0.505 & 0.324 & 0.105 & -1.141 & 0.130 & -1.558 & 0.119 & & & & & \\
\hline Adults & Frith et al $(2011) \mathrm{Cl}$ & -0.128 & 0.314 & 0.099 & -0.744 & 0.487 & -0.409 & 0.683 & & & & & \\
\hline Adults & Gallegos et al (2016) & -0.032 & 0.192 & 0.037 & -0.409 & 0.344 & $\begin{array}{lll}4 & -0.168 \\
\end{array}$ & 0.867 & & & & & \\
\hline Adults & Hong et al (2017) & -0.283 & 0.259 & 0.067 & -0.792 & 0.226 & -1.090 & 0.276 & & & & & \\
\hline Adults & Li, A et al (2006) & -0.448 & 0.186 & 0.035 & -0.813 & -0.082 & -2.402 & 0.016 & & & & & \\
\hline Adults & Schitter et al (2016) & -0.385 & 0.263 & 0.069 & -0.900 & 0.131 & -1.462 & 0.144 & & & & & \\
\hline Adults & & -0.330 & 0.099 & 0.010 & -0.524 & -0.137 & -3.345 & 0.001 & & & & & \\
\hline The olders & Frye et al (2007) & -0.454 & 0.306 & 0.093 & -1.053 & 0.145 & $5-1.485$ & 0.138 & & & & & \\
\hline The olders & Li. F et al (2001) & -0.731 & 0.245 & 0.060 & -1.211 & -0.251 & $\begin{array}{ll}-1.400 \\
1\end{array}$ & 0.003 & & & & & \\
\hline The olders & Liao et al (2018) & -0.579 & 0.197 & 0.039 & -0.966 & -0.192 & -2.931 & 0.003 & & & & & \\
\hline The olders & Noradechanunt et al (2017) & -0.140 & 0.450 & 0.203 & $\begin{array}{l}-0.900 \\
-1.022\end{array}$ & 0.742 & -0.311 & 0.756 & & & & & \\
\hline The olders & Zhang et al (2014) & -1.378 & 0.292 & 0.085 & $\begin{array}{l}-1.022 \\
-1.951\end{array}$ & -0.805 & -4.715 & 0.000 & & & & & \\
\hline The olders & & -0.701 & 0.134 & 0.018 & -0.964 & -0.439 & -5.237 & 0.000 & & & & & \\
\hline \multirow[t]{3}{*}{ Overall } & & -0.505 & 0.185 & 0.034 & -0.868 & $\begin{array}{l}-0.142 \\
-0.43\end{array}$ & $\begin{array}{ll}2.2727 \\
\end{array}$ & 0.006 & & & & & \\
\hline & & & & & & & & & -2.00 & -1.00 & 0.00 & 1.00 & 2.00 \\
\hline & & & & & & & & & & Favours A & & Favours B & \\
\hline
\end{tabular}

\section{Meta Analysis}

Figure 8. Forest plot for moderator (age) analysis (CI: circuit training; AE: aerobic exercise).

\subsection{Moderator Analysis for Experimental Design}

Studies included both RCT and non-RCT designs. There was no significant moderator effect of study design with the random-effect model $(\mathrm{Q}=0.197, \mathrm{df}=1, p=0.657$; Figure 9).

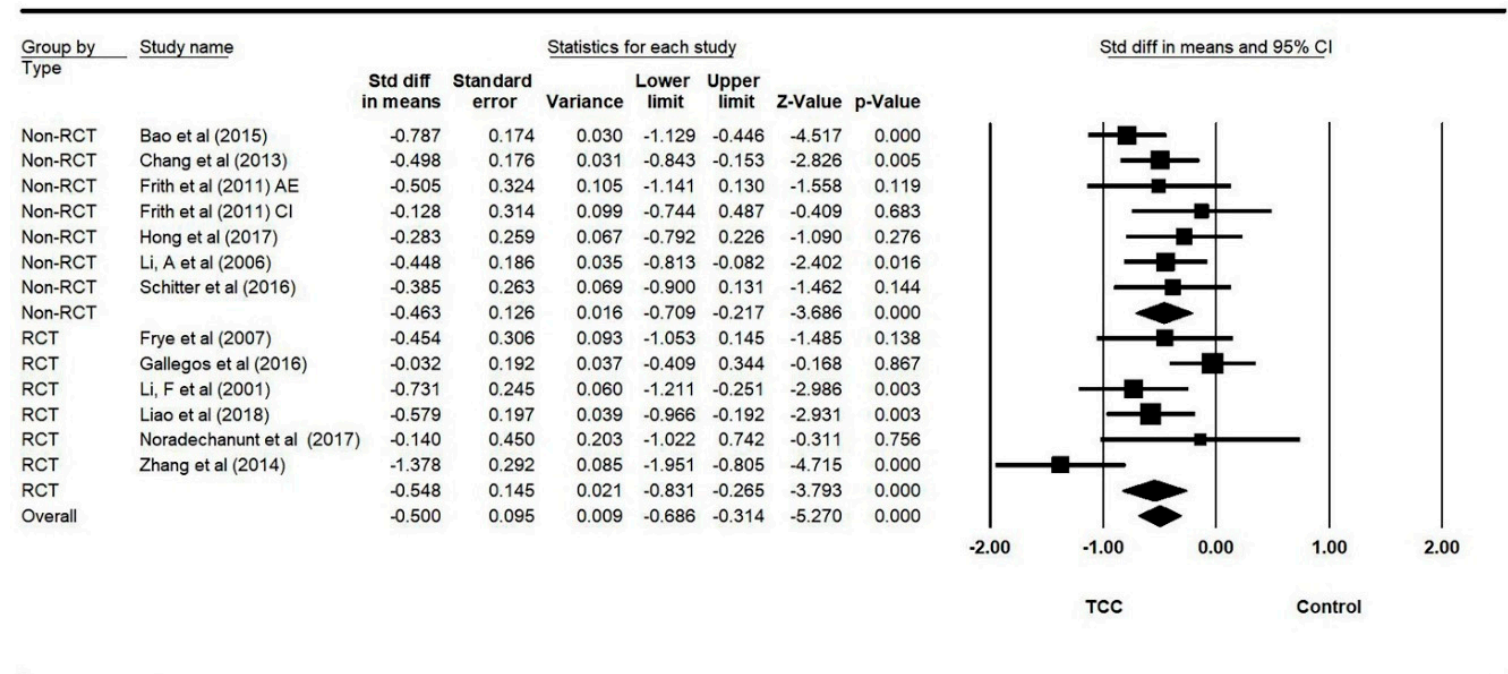

\section{Meta Analysis}

Figure 9. Forest plot for moderator (experimental design) analysis (CI: circuit training; AE: aerobic exercise).

\section{Discussion}

Although the positive effect of TCC on negative emotions (anxiety and depression) have been widely demonstrated in many clinical studies [26-29], the interest on its preventive effects among non-clinical populations have only emerged in recent years. In this study, a systematic meta-analysis was comprehensively conducted to investigate the effects of TCC on negative emotions (anxiety and depression) among apparently healthy individuals, which showed that the effect of TCC practice on anxiety and depression reached moderate to large effect sizes. Additionally, our meta-analysis also suggests that TCC is an appropriate practice to prevent depression and anxiety among individuals across the adult lifespan.

The significant effects of TCC on depression and anxiety might be attributed to its meditative components. Several studies support the meditative effect of TCC, which shows that TCC practitioners 
have a high level of non-reactivity to inner experiences [11,30]. TCC, a traditional Chinese martial art, involving mindfulness-based slow and continuous with highly choreographed movements [31], emphasizes relaxation of musculoskeletal and the empty state of mind [32]. It is plausible that TCC reduces negative emotions by enhancing attentional control, improving emotion regulation and altering self-awareness [33] during the meditative movements. Such improvements in meditative level induced by TCC practice may result in decreased depression and anxiety [10,32,34-36]. Hence, the mindfulness-based movements might play an importance role in decreasing the feeling of anxiety $[28,37]$ and depression $[38,39]$.

On the other hand, abdominal breathing during TCC practice is likely another crucial component to decrease depression and anxiety. Abdominal breathing is usually conducted by contracting the diaphragm and expanding the abdomen. During TCC practice, the practitioners perform a series of slow movements accompanied by deep breathing. Such breathing style could help the body reach relaxation and exert a positive impact on negative emotions. The potential mechanism might be related to optimized function of the autonomic nervous system, especially altered heart rate variability (HRV). Wei et al. (2015) detected that TCC experts showed improved HRV compared to healthy controls [40]. Additionally, it was observed that HRV was significantly increased after practice among TCC individuals with depression [38]. The enhanced HRV is also a strong protective factor of cardiovascular diseases (CVD), which suggests that TCC may be an important alternative medicine for the prevention and treatment of CVD [41]. Notably, HRV is used as a reliable index of autonomic nervous modulation as well as an objective measurement of emotional regulation capacity [42,43]. Therefore, improved HRV induced by TCC practice indicates better balance between the sympathetic nervous system and parasympathetic nervous system, which leads to better emotional regulation [44]. TCC practice might alter HRV by increasing the breathing amplitude and hence enhance the capability of emotional regulation.

One mechanism accounting for the change of negative emotions might due to exercise-induced neurotrophic factor production. It is well-documented from human and animal studies that aerobic exercise produces a benefit on brain health and anxiety/depressive reduction [45]. A neurobiological mechanism is that physical exercise increases the production of insulin-like growth factor (IGF-1) and brain-derived neurotrophic factor (BDNF) [46]. IGF-1 is a critical longevity related biomarker, which plays a prominent role in the development of the central nervous system $[47,48]$ and cell proliferation [49]. Increasing (IGF-1) is associated with improved mood, anxiety status [50] and depression [51]. Participants engaging in exercise have observed increases in IGF-1, improved positive feelings and decreased anxiety $[47,52]$. Brain-derived neurotrophic factor (BDNF) is another critical neurotrophic factor for neural plasticity and depressive-like behaviors [53-55]. Patients with depression show lower serum BDNF than healthy controls [56]. After six months of TCC practice, an upregulation of BDNF were detected among older adults with amnestic mild cognitive impairment (a-MCI) [57]. Similarly, studies on other mind-body exercise also have shown a positive effect of TCC on serum BDNF among depressed patients [58,59] and healthy people [60]. A randomized one-year aerobic exercise program for healthy older adults observed that exercise increased serum levels of BDNF and IGF-1 [61], which are protective neurobiological markers for emotional disorders [62,63].

In this study, we also performed a subgroup analysis to investigate the moderator effect of age. We found a significant moderation effect of age, which depicted a better negative emotion beneficial effect among older adults than younger adults. However, despite this moderation effect, our findings demonstrate TCC benefits on negative emotions occur in both younger and older adults. In view of its slow movement with mild to moderate intensity, TCC is believed to be mostly suitable for the elderly. For instance, it could reduce anxiety among older adults with anxiety disorder $[64,65]$ and depression $[38,66]$. Moreover, since it originates from Taoism, TCC practice stresses the harmony of mind and body as well as the simultaneous state of relaxation and concentration. Currently, clinical studies (e.g., attention deficit hyperactivity disorder, asthma) also found beneficial effects on emotion among adolescence [26,27] and children [28,67], as well as young adults [29,68]. TCC contains multiple 
components including mindfulness, deep breathing and aerobic exercise, which contribute together to its overall effect of negative emotions towards all age populations. Given that there was only one adolescence study in the meta-analysis, we excluded it in the subgroup analysis. Thus, our results included studies from only younger adults and older adults. Previous studies demonstrate that the onset of the majority of emotional disorders occurs during adolescences [69]. Thus, future research should evaluate the effect of TCC practice on emotional disorders among adolescents.

Moreover, a subgroup analysis comparing the difference between RCT studies and non-RCT studies was conducted. Although the results did not show a significant difference between these two study designs, there were only a few RCTs. Given the powerful design of an RCT, future studies on this topic, when feasible, should implement an RCT.

\section{Limitations}

When interpreting the findings of this meta-analysis, it is important to consider that even though all of the included studies used TCC as the intervention skill, the intervention involved included both single and mixed forms combining TCC with other mind-body practices. This may render difficulty in revealing the real effect of mono TCC on emotional outcomes. Moreover, these included studies measured outcomes with different scales, which might lead to diversity of study results, as well as heterogeneity in effect size. However, the findings still support the predictions that TCC practice can reduce negative emotions in non-clinical populations.

\section{Conclusions}

This systematic review, based on existing literature, both in English and Chinese, showed that TCC practice is moderately to largely effective in improving negative emotions, decreasing depression and reducing anxiety in apparently healthy individuals. Our findings suggest that TCC could be considered a worthy complementary non-pharmacological resource for depression and anxiety, which has great implications for the prevention of emotional disorders and mental health promotion. To reach a firm conclusion, more large-scale studies with robust experimental design like randomized controlled trial, especially in young adults are needed, along with follow-up assessment.

Author Contributions: Conceptualization, G.-X.W.; methodology, S.Z., L.Z., Y.Y., L.-Z.C. and G.-X.W.; validation and formal analysis, Y.Y., L.-Z.C. and S.Z.; data curation, S.Z., L.Z. and Y.Y.; writing-Preparation of the original draft, S.Z., P.D.L., L.Z., P.M.S. and G.-X.W.; writing-Review and editing, L.Z., P.M.S., P.D.L. and G.-X.W.; visualization, S.Z. and L.-Z.C.; supervision, G.-X.W.; project administration, G.-X.W.; funding acquisition, G.-X.W.

Funding: This research was funded by the Key Laboratory of Mental Health and Key Laboratory of Behavioral Science, Institute of Psychology, Chinese Academy of Sciences; as well as by the National Natural Science Foundation of China (grant number 31671163).

Conflicts of Interest: The authors declare no conflict of interest. The funders had no role in the design of the study; in the collection, analyses, or interpretation of data; in the writing of the manuscript, or in the decision to publish the results.

\section{References}

1. Organization, W.H. Depression and Other Common Mental Disorders; Global Health Estimates: Geneva, Switzerland, 2017.

2. Frankish, H.; Boyce, N.; Horton, R. Mental health for all: A global goal. Lancet 2018, 392, $1493-1494$. [CrossRef]

3. Farach, F.J.; Pruitt, L.D.; Jun, J.J.; Jerud, A.B.; Zoellner, L.A.; Roy-Byrne, P.P. Pharmacological treatment of anxiety disorders: Current treatments and future directions. J. Anxiety Disord. 2012, 26, 833-843. [CrossRef] [PubMed]

4. Rosenblat, J.D.; Simon, G.E.; Sachs, G.S.; Deetz, I.; Doederlein, A.; DePeralta, D.; Dean, M.M.; McIntyre, R.S. Treatment effectiveness and tolerability outcomes that are most important to individuals with bipolar and unipolar depression. J. Affect. Dis. 2019, 243, 116-120. [CrossRef] 
5. WHO. Global Strategy on Diet, Physical Activity and Health; WHO: Geneva, Switzerland; Available online: https://www.who.int/dietphysicalactivity/pa/en/ (accessed on 1 August 2019).

6. Sim, M.K. Treatment of disease without the use of drugs I. Research on biofeedback training. Singap. Med. J. 1976, 17, 167.

7. Li, F.; Duncan, T.E.; Duncan, S.C.; McAuley, E.; Chaumeton, N.R.; Harmer, P. Enhancing the Psychological Well-Being of Elderly Individuals Through Tai Chi Exercise: A Latent Growth Curve Analysis. Struct. Equ. Model. A Multidiscip. J. 2001, 8, 53-83. [CrossRef]

8. Steptoe, A.; Wardle, J.; Fuller, R.; Holte, A.; Justo, J.; Sanderman, R.; Wichstrom, L. Leisure-time physical exercise: Prevalence, attitudinal correlates, and behavioral correlates among young Europeans from 21 countries. Prev. Med. 1997, 26, 845-854. [CrossRef]

9. Zou, L.; Yeung, A.; Li, C.; Wei, G.X.; Chen, K.W.; Kinser, P.A.; Chan, J.S.M.; Ren, Z. Effects of Meditative Movements on Major Depressive Disorder: A Systematic Review and Meta-Analysis of Randomized Controlled Trials. J. Clin. Med. 2018, 7, 195. [CrossRef]

10. Stonerock, G.L.; Hoffman, B.M.; Smith, P.J.; Blumenthal, J.A. Exercise as Treatment for Anxiety: Systematic Review and Analysis. Ann. Behav. Med. 2015, 49, 542-556. [CrossRef]

11. Yang, J.; Liu, Z.; Liu, S.; Li, L.; Zheng, L.; Guo, X. The emotional stability of elders with Tai Chi experience in the sequential risk-taking task. Psych J. 2019. [CrossRef] [PubMed]

12. Zou, L.; Loprinzi, P.D.; Yeung, A.S.; Zeng, N.; Huang, T. The beneficial effects of mind-body exercises for people with mild cognitive impairment: A systematic review with meta-analysis. Arch. Phys. Med. Rehabil. 2019, 100, 1556-1573. [CrossRef]

13. Zou, L.; Han, J.; Li, C.; Yeung, A.S.; Hui, S.S.; Tsang, W.W.N.; Ren, Z.; Wang, L. Effects of Tai Chi on lower limb proprioception in adults aged over 55: A systematic review and meta-analysis. Arch. Phys. Med. Rehabil. 2019, 100, 1102-1113. [CrossRef] [PubMed]

14. Caldwell, K.; Emery, L.; Harrison, M.; Harrison, M.; Greeson, J. Changes in mindfulness, well-being, and sleep quality in college students through taijiquan courses: A cohort control study. J. Altern. Complement. Med. 2011, 17, 931-938. [CrossRef] [PubMed]

15. Zou, L.; Sasaki, J.E.; Zeng, N.; Wang, C.; Sun, L. A systematic review with meta-analysis of mindful exercises on rehabilitative outcoems among poststroke patients. Arch. Phys. Med. Rehabil. 2018, 99, 2355-2364. [CrossRef] [PubMed]

16. Orr, R.; Tsang, T.; Lam, P.; Comino, E.; Singh, M.F. Mobility Impairment in Type 2 Diabetes: Association with muscle power and effect of Tai Chi intervention. Diabetes Care 2006, 29, 2120-2122. [CrossRef] [PubMed]

17. Zou, L.; Wang, H.; Xiao, Z.; Fang, Q.; Zhang, M.; Li, T.; Du, G.; Liu, Y. Tai Chi for health benefits in patients with multiple sclerosis: A systematic review. PLoS ONE 2017, 12, e0170212. [CrossRef] [PubMed]

18. Lan, C.; Chen, S.Y.; Wong, M.K.; Lai, J.S. Tai Chi Chuan exercise for patients with cardiovascular disease. Evidence-Based Complementray and Alternative Medicine. Evid. Based Complement. Altern. Med. 2013, 2013, 983208. [CrossRef] [PubMed]

19. Wang, C.; Schmid, C.H.; Fielding, R.A.; Harvey, W.F.; Reid, K.F.; Price, L.L.; Driban, J.B.; Kalish, R.; Rones, R.; McAlindon, T. Effect of Tai Chi versus aerobic exercise for fibromyalgia: Comparative effectiveness randomized controlled trial. BMJ 2018, 360, 851. [CrossRef]

20. Cheon, S.M.; Chae, B.K.; Sung, H.R.; Lee, G.C.; Kim, J.W. The Efficacy of Exercise Programs for Parkinson's Disease: Tai Chi versus Combined Exercise. J. Clin. Neurol. 2013, 9, 237-243. [CrossRef]

21. Hoffmann-Smith, K.A.; Ma, A.; Yeh, C.-T.; DeGuire, N.L.; Smith, J.P. The Effect of Tai Chi in Reducing Anxiety in an Ambulatory Population. J. Complement. Integr. Med. 2009, 6. [CrossRef]

22. Moher, D.; Shamseer, L.; Clarke, M.; Ghersi, D.; Liberati, A.; Petticrew, M.; Shekelle, P.; Stewart, L.A. Preferred reporting items for systematic review and meta-analysis protocols (PRISMA-P) 2015 statement. Syst. Rev. 2015, 4, 1. [CrossRef]

23. Blobaum, P. Physiotherapy Evidence Database (PEDro). J. Med. Libr. Assoc. 2006, 94, 477.

24. Zheng, S.; Kim, C.; Lal, S.; Meier, P.; Sibbritt, D.; Zaslawski, C. The Effects of Twelve Weeks of Tai Chi Practice on Anxiety in Stressed But Healthy People Compared to Exercise and Wait-List Groups-A Randomized Controlled Trial. J. Clin. Psychol. 2017, 74, 83-92. [CrossRef] [PubMed]

25. Zhang, X.; Ni, X.; Chen, P. Study about the effects of different fitness sports on cognitive function and emotion of the aged. Cell Biochem. Biophys. 2014, 70, 1591-1596. [CrossRef] [PubMed] 
26. Chang, C.; Tsai, G.; Hsieh, C.-J. Psychological, immunological and physiological effects of a Laughing Qigong Program (LQP) on adolescents. Complement. Ther. Med. 2013, 21, 660-668. [CrossRef] [PubMed]

27. Field, T. Exercise research on children and adolescents. Complement. Ther. Clin. Pract. 2012, 18, 54-59. [CrossRef]

28. Chiang, L.C.; Ma, W.F.; Huang, J.L.; Tseng, L.F.; Hsueh, K.C. Effect of relaxation-breathing training on anxiety and asthma signs/symptoms of children with moderate-to-severe asthma: A randomized controlled trial. Int. J. Nurs. Stud. 2009, 46, 1061-1070. [CrossRef]

29. Awelewa, O.O.; Caldwell, K.L.; Triplett, N.T.T.; Bergquist, J.J.; Bergman, S.; Collier, S.R. Sex Differences In Autonomic Function Exist Following Tai Chi Chuan Training In Young Adults With High Anxiety. Med. Sci. Sports Exerc. 2015, 47, 752-753. [CrossRef]

30. Black, D.S.; Irwin, M.R.; Olmstead, R.; Ji, E.; Crabb Breen, E.; Motivala, S.J. Tai Chi Meditation Effects on Nuclear Factor-кB Signaling in Lonely Older Adults: A Randomized Controlled Trial. Psychother. Psychosom. 2014, 83, 315-317. [CrossRef]

31. Leung, D.P.; Chan, C.K.; Tsang, H.W.; Tsang, W.W.; Jones, A.Y. Tai chi as an intervention to improve balance and reduce falls in older adults: A systematic and meta-analytical review. Altern. Ther. Health Med. 2011, 17, $40-48$.

32. Zou, L.; Yeung, A.; Quan, X.; Hui, S.S.; Hu, X.; Chan, J.S.M.; Wang, C.; Boyden, S.D.; Sun, L.; Wang, H. Mindfulness-Based Baduanjin Exercise for Depression and Anxiety in People with Physical or Mental Illnesses: A Systematic Review and Meta-Analysis. Int. J. Environ. Res. Public Health 2018, 15, 321. [CrossRef]

33. Tang, Y.-Y.; Jiang, C.; Tang, R. How Mind-Body Practice Works-Integration or Separation? Front. Psychol. 2017, 8, 866. [CrossRef] [PubMed]

34. Chen, K.W.; Berger, C.C.; Eric, M.; Darlene, F.; Jessica, M.; Laya, D.; Lejuez, C.W. Meditative therapies for reducing anxiety: A systematic review and meta-analysis of randomized controlled trials. Depress. Anxiety 2012, 29, 545-562. [CrossRef] [PubMed]

35. Kirkwood, G.; Rampes, H.; Tuffrey, V.; Richardson, J.; Pilkington, K. Yoga for anxiety: A systematic review of the research evidence. Br. J. Sports Med. 2005, 39, 884-891. [CrossRef] [PubMed]

36. Goyal, M.; Singh, S.; Sibinga, E.M.; Gould, N.F.; Rowland-Seymour, A.; Sharma, R.; Berger, Z.; Sleicher, D.; Maron, D.D.; Shihab, H.M. Meditation Programs for Psychological Stress and Well-being: A Systematic Review and Meta-analysis. Deutsche Zeitschrift Fuer Akupunktur 2014, 57, 26-27. [CrossRef]

37. Cho, H.; Ryu, S.; Noh, J.; Lee, J. The Effectiveness of Daily Mindful Breathing Practices on Test Anxiety of Students. PLoS ONE 2016, 11, e0164822. [CrossRef]

38. Liu, J.; Xie, H.; Liu, M.; Wang, Z.; Zou, L.; Yeung, A.S.; Hui, S.S.; Yang, Q. The Effects of Tai Chi on Heart Rate Variability in Older Chinese Individuals with Depression. Int. J. Environ. Res. Public Health 2018, 15, 2771. [CrossRef]

39. Park, Y.J. Effect of Tai Chi Exercise Program on Depression, Self-esteem, and Self-efficacy of Nursing College Students. J. Learn.-Cent. Curric. Instr. 2017, 17, 805-820. [CrossRef]

40. Wei, G.X.; Li, Y.F.; Yue, X.L.; Ma, X.; Chang, Y.K.; Yi, L.Y.; Li, J.C.; Zuo, X.N. Tai Chi Chuan modulates heart rate variability during abdominal breathing in elderly adults. Psych J. 2016, 5, 69-77. [CrossRef] [PubMed]

41. Yang, G.; Li, W.; Cao, H.; Klupp, N.; Liu, J.; Bensoussan, A.; Kiat, H.; Chang, D. Does Tai Chi improve psychological well-being and quality of life in patients with cardiovascular disease and/or cardiovascular risk factors? A systematic review protocol. BMJ Open 2017, 7, e014507. [CrossRef] [PubMed]

42. Appelhans, B.M.; Luecken, L.J. Heart rate variability as an index of regulated emotional responding. Rev. Gen. Psychol. 2006, 10, 229-240. [CrossRef]

43. Visted, E.; Sorensen, L.; Osnes, B.; Svendsen, J.L.; Binder, P.E.; Schanche, E. The Association between Self-Reported Difficulties in Emotion Regulation and Heart Rate Variability: The Salient Role of Not Accepting Negative Emotions. Front. Psychol. 2017, 8, 328. [CrossRef] [PubMed]

44. Mather, M.; Thayer, J.F. How heart rate variability affects emotion regulation brain networks. Curr. Opin. Behav. Sci. 2018, 19, 98-104. [CrossRef] [PubMed]

45. Pietrelli, A.; Lopez-Costa, J.; Goñi, R.; Brusco, A.; Basso, N. Aerobic exercise prevents age-dependent cognitive decline and reduces anxiety-related behaviors in middle-aged and old rats. Neuroscience 2011, 202, 252-266. [CrossRef] [PubMed] 
46. Sleiman, S.F.; Henry, J.; Al-Haddad, R.; El Hayek, L.; Abou Haidar, E.; Stringer, T.; Ulja, D.; Karuppagounder, S.S.; Holson, E.B.; Ratan, R.R.; et al. Exercise promotes the expression of brain derived neurotrophic factor (BDNF) through the action of the ketone body beta-hydroxybutyrate. eLife 2016, 5 . [CrossRef] [PubMed]

47. Gallegos, A.M.; Hoerger, M.; Talbot, N.L.; Krasner, M.S.; Knight, J.M.; Moynihan, J.A.; Duberstein, P.R. Toward identifying the effects of the specific components of Mindfulness-Based Stress Reduction on biologic and emotional outcomes among older adults. J. Altern. Complement. Med. 2013, 19, 787-792. [CrossRef] [PubMed]

48. Dyer, A.H.; Vahdatpour, C.; Sanfeliu, A.; Tropea, D. The role of Insulin-Like Growth Factor 1 (IGF-1) in brain development, maturation and neuroplasticity. Neuroscience 2016, 325, 89-99. [CrossRef] [PubMed]

49. Janelsins, M.C.; Davis, P.G.; Wideman, L.; Katula, J.A.; Sprod, L.K.; Peppone, L.J.; Palesh, O.G.; Heckler, C.E.; Williams, J.P.; Morrow, G.R.; et al. Effects of Tai Chi Chuan on insulin and cytokine levels in a randomized controlled pilot study on breast cancer survivors. Clin. Breast Cancer 2011, 11, 161-170. [CrossRef]

50. Cassilhas, R.C.; Antunes, H.K.; Tufik, S.; de Mello, M.T. Mood, anxiety, and serum IGF-1 in elderly men given 24 weeks of high resistance exercise. Percept. Mot. Ski. 2010, 110, 265-276. [CrossRef]

51. Mitschelen, M.; Yan, H.; Farley, J.A.; Warrington, J.P.; Han, S.; Herenu, C.B.; Csiszar, A.; Ungvari, Z.; Bailey-Downs, L.C.; Bass, C.E.; et al. Long-term deficiency of circulating and hippocampal insulin-like growth factor I induces depressive behavior in adult mice: A potential model of geriatric depression. Neuroscience 2011, 185, 50-60. [CrossRef]

52. Jiang, P.; Dang, R.L.; Li, H.D.; Zhang, L.H.; Zhu, W.Y.; Xue, Y.; Tang, M.M. The Impacts of Swimming Exercise on Hippocampal Expression of Neurotrophic Factors in Rats Exposed to Chronic Unpredictable Mild Stress. Evid.-Based Complement. Altern. Med. 2014, 2014, 729827-729828. [CrossRef]

53. Qiao, H.; An, S.C.; Xu, C.; Ma, X.M. Role of proBDNF and BDNF in dendritic spine plasticity and depressive-like behaviors induced by an animal model of depression. Brain Res. 2017, 1663, 29-37. [CrossRef]

54. Binder, D.K.; Scharfman, H.E. Mini Review. Growth Factors 2009, 22, 123-131. [CrossRef]

55. Marais, L.; Stein, D.J.; Daniels, W.M.U. Exercise increases BDNF levels in the striatum and decreases depressive-like behavior in chronically stressed rats. Metab. Brain Dis. 2009, 24, 587-597. [CrossRef]

56. Karege, F.; Perret, G.; Bondolfi, G.; Schwald, M.; Bertschy, G.; Aubry, J.M. Decreased serum brain-derived neurotrophic factor levels in major depressed patients. Psychiatry Res. 2002, 109, 143-148. [CrossRef]

57. Sungkarat, S.; Boripuntakul, S.; Kumfu, S.; Lord, S.R.; Chattipakorn, N. Tai Chi Improves Cognition and Plasma BDNF in Older Adults with Mild Cognitive Impairment: A Randomized Controlled Trial. Neurorehabilit. Neural Repair 2018, 32, 142-149. [CrossRef]

58. Naveen, G.H.; Thirthalli, J.; Rao, M.G.; Varambally, S.; Christopher, R.; Gangadhar, B.N. Positive therapeutic and neurotropic effects of yoga in depression: A comparative study. Indian J. Psychiatry 2013, 55, S400-S404. [CrossRef] [PubMed]

59. Naveen, G.H.; Varambally, S.; Thirthalli, J.; Rao, M.; Christopher, R.; Gangadhar, B.N. Serum cortisol and BDNF in patients with major depression-effect of yoga. Int. Rev. Psychiatry 2016, 28, 273-278. [CrossRef]

60. Cahn, B.R.; Goodman, M.S.; Peterson, C.T.; Maturi, R.; Mills, P.J. Yoga, Meditation and Mind-Body Health: Increased BDNF, Cortisol Awakening Response, and Altered Inflammatory Marker Expression after a 3-Month Yoga and Meditation Retreat. Front. Hum. Neurosci. 2017, 11, 315. [CrossRef] [PubMed]

61. Voss, M.W.; Erickson, K.I.; Prakash, R.S.; Chaddock, L.; Kim, J.S.; Alves, H.; Szabo, A.; Phillips, S.M.; Wójcicki, T.R.; Mailey, E.L.; et al. Neurobiological markers of exercise-related brain plasticity in older adults. Brain Behav. Immun. 2012, 28, 90-99. [CrossRef]

62. Hosang, G.M.; Shiles, C.; Tansey, K.E.; McGuffin, P.; Uher, R. Interaction between stress and the BDNF Val66Met polymorphism in depression: A systematic review and meta-analysis. BMC Med. 2014, $12,7$. [CrossRef]

63. Chen, S.Z.; Jiang, H.T.; Liu, Y.; Hou, Z.H.; Yue, Y.Y.; Zhang, Y.Q.; Zhao, F.Y.; Xu, Z.; Li, Y.H.; Mou, X.D.; et al. Combined serum levels of multiple proteins in tPA-BDNF pathway may aid the diagnosis of five mental disorders. Sci. Rep. 2017, 7, 6871-6879. [CrossRef]

64. Song, Q.-H.; Shen, G.-Q.; Xu, R.-M.; Zhang, Q.-H.; Ma, M.; Guo, Y.-H.; Zhao, X.-P.; Han, Y.-B. Effect of Tai Chi exercise on the physical and mental health of the elder patients suffered from anxiety disorder. Int. J. Physiol. Pathophysiol. Pharmacol. 2014, 6, 55-60. [PubMed] 
65. Chang, M.Y.; Yeh, S.C.; Chu, M.C.; Wu, T.M.; Huang, T.H. Associations between Tai Chi Chung program, anxiety, and cardiovascular risk factors. American journal of health promotion. Am. J. Health-Syst. Pharm. 2013, 28, 16-22. [CrossRef] [PubMed]

66. Siu, K.-C.; Padilla, C.; Rajaram, S.S. The interrelationship between balance, Tai Chi and depression in Latino older adults. Aging Clin. Exp. Res. 2017, 29, 395-401. [CrossRef]

67. Herbert, A.; Esparham, A. Mind-Body Therapy for Children with Attention-Deficit/Hyperactivity Disorder. Children 2017, 4, 31. [CrossRef]

68. Caldwell, K.L.; Bergman, S.M.; Collier, S.R.; Triplett, N.T.; Quin, R.; Bergquist, J.; Pieper, C.F. Effects of Tai Chi Chuan on anxiety and sleep quality in young adults: Lessons from a randomized controlled feasibility study. Nat. Sci. Sleep 2016, 8, 305-314. [CrossRef] [PubMed]

69. Bao, X.; Jin, K. The beneficial effect of Tai Chi on self-concept in adolescents. Int. J. Psychol. 2015, 50, 101-105. [CrossRef]

(C) 2019 by the authors. Licensee MDPI, Basel, Switzerland. This article is an open access article distributed under the terms and conditions of the Creative Commons Attribution (CC BY) license (http://creativecommons.org/licenses/by/4.0/). 